\title{
Dinamika Kontrol Sosial Keluarga dan Teman Sebaya pada Remaja Berisiko Penyalahgunaan NAPZA
}

\author{
Hesti Kusumastuti ${ }^{1} \mathcal{E}$ M. Noor Rochman Hadjam² \\ Fakultas Psikologi Universitas Gadjah Mada
}

\begin{abstract}
The purpose of this research is to know in depth how the dynamics of social control family and peers on adolescents who are at risk of drug abuse. Method: This research method using qualitative research method, which uses data collecting interviews and observation. Participant: This study focused on participants who are at risk of drug abuse with the following criteria: (a) willing to be a participant, (b) gender to male or female, (c) \pm adolescents aged 15-18 years, (d) adolescents who are indicated are at risk of drug abuse. Result: The results of this study indicate that adolescents who are at risk of drug abuse are smoking and drinking. High risk factors cause adolescents to be at risk for drug abuse, ie family conflicts, negative parental models, involvement of negative activities with peers, and peer-to-peer conformity. This is supported by the weakness of protection factors in adolescent behavior at risk of drug abuse. Weak family controls supported by weak peer control will increase the risk rate for adolescent drug abuse behavior. This suggests that family and peer social controls are very influential to reduce the risk of adolescent drug abusers, especially in prevention and intervention.
\end{abstract}

Keywords: adolescence; drug abuse; family; social control; peers

Abstrak. Tujuan dari penelitian ini adalah untuk mengetahui secara mendalam dinamika kontrol sosial keluarga dan teman sebaya pada remaja yang berisiko penyalahgunaan NAPZA. Metode penelitian kualitatif, yaitu menggunakan pengumpulan data wawancara dan observasi. Penelitian berfokus pada informan yang berisiko penyalahgunaan NAPZA dengan kriteria sebagai berikut: (a) bersedia menjadi peserta, (b) jenis kelamin terhadap laki-laki atau perempuan, (c) \pm remaja berusia 15-18 tahun, (d) Remaja yang diindikasikan berisiko penyalahgunaan NAPZA. Hasil penelitian ini adalah remaja yang berisiko penyalahgunaan NAPZA berawal dari perilaku merokok dan minum-minuman keras. Faktor risiko yang tinggi menyebabkan remaja berisiko penyalahgunaan NAPZA, yaitu konflik keluarga, model orang tua negatif, keterlibatan kegiatan negatif dengan teman, dan konformitas teman. Hal ini didukung oleh lemahnya faktor perlindungan perilaku remaja terhadap risiko penyalahgunaan narkoba. Kontrol keluarga lemah yang didukung oleh kontrol teman yang kuat akan meningkatkan tingkat risiko perilaku penyalahgunaan NAPZA remaja. Hal ini menunjukkan bahwa kontrol sosial keluarga dan teman sangat berpengaruh untuk mengurangi risiko penyalahgunaan NAPZA remaja terutama dalam pencegahan.

Kata Kunci : keluarga; kontrol sosial; penyalahgunaan NAPZA; remaja; teman sebaya

\footnotetext{
${ }^{1}$ Korespondensi mengenai isi artikel ini dapat dilakukan melalui hesti.kusumastuti92@mail.ugm.ac.id

${ }^{2}$ Atau melalui nrochman@ugm.ac.id
} 
NAPZA merupakan singkatan dari Narkotika, Psikotropika, dan Zat Adiktif lainnya. Terminologi narkoba familiar digunakan oleh aparat penegak hukum seperti polisi (seperti di dalamnya Badan Narkotika Nasional), jaksa, hakim, dan petugas pemasyarakatan. Penelitian ini memakai istilah NAPZA di mana, masingmasing kategori dari narkotika, psikotropika, dan zat psikoaktif mempunyai berbagai jenis.

Menurut Pedoman Penggolongan dan Diagnosis Gangguan Jiwa - III (Maslim, 2001) penyalahgunaan NAPZA merupakan sebuah gangguan yang luas dan berbeda keparahannya (dari intoksinasi tanpa komplikasi dan penggunaan yang merugikan sampai gangguan psikotik yang jelas dan dimensia, tetapi semua itu diakibatkan oleh karena penggunaan satu atau lebih zat psikoaktif (dengan atau tanpa resep dokter). Penekanan pada definisi ini adalah penggunaan satu atau lebih, di mana penggunaan satu jenis saja sudah dikatakan sebagai bentuk penyalahgunaan NAPZA, tentunya dengan memberikan bukti bahwa penggunaan zat tersebut dilakukan akhir-akhir atau saat ini.

Kasus yang terjadi pada penyalahgunaan narkotika, psikotropika, dan zat adiktif lainnya (NAPZA) menjadi kasus kompleks yang tidak muncul dari satu faktor. Faktor-faktor yang kompleks tersebut terdiri dari faktor internal maupun eksternal. Faktor internal menyangkut individu sebagai pribadi (personality). Faktor internal antara lain meliputi pengetahuan, sikap, self-efficacy, sensasi seeking, dan telah dikaji oleh Afiatin (2008); Gatins \& White (2006); Gerra, et al. (2004); Hadad, Shotar, Umlauf, \& Al-Zyoud (2010); dan Puente, Gutierrez, Abella'n, \& Lopez (2008). Sedangkan faktor eksternal antara lain: relasi dengan teman sebaya, kondisi keluarga, di sekolah, di lingkungan sekitar, serta telah dilakukan kajian antara lain oleh Akers, et al. (1979); Akers, et al. (2007); Barnes, et al. (2006); Calafat, et al. (2008); Connel, et al. (2010); Davis, et al. (2004); Dishion, et al. (1999); Drapela (2006), Fleming, et al. (2010); dan Kaplow, et al. (2002).

Berdasarkan data penelitian Saams dapat diketahui lebih dari 56,9\% umur responden masuk LAPAS antara 15-17 tahun; 32,6\% berusia 18-20 tahun; 6,9\% berusia 13-14 tahun. Penyalahgunaan NAPZA paling besar adalah usia sekolah, yaitu $80 \%$ dari penyalahgunaanan NAPZA usia sekolah SMP dan SMA (www.bnn.go.id).

Menurut Budiyanto (2012) terdapat fenomena bahwa sepuluh kabupaten/kota di Jawa Tengah rawan peredaran narkoba, sepuluh kabupaten/kota tersebut adalah Kota Semarang, Solo, Kabupaten Banyumas, Cilacap, Magelang, Sragen, Jepara, Batang, Pemalang, dan Wonosobo. Pengguna narkoba $70 \%$ pekerja dan $20 \%$ dari kalangan pelajar atau mahasiswa (www.tvonenews.com).

Berdasarkan wawancara yang dilakukan oleh pihak Satuan Reserse Khusus Narkoba Polresta Kota Solo pada bulan Januari 2017 memaparkan bahwa selama tahun 2015 memiliki kasus narkoba berjumlah 107 dan tersangka berjumlah 120 orang. Pada tahun 2016 memiliki peningkatan kasus narkoba di Kota Solo berjumlah 133 dan tersangka berjumlah 159 orang.

Peneliti melakukan wawancara awal untuk mengetahui kondisi di Kota Solo terkait penyalahgunaan NAPZA. Dari hasil wawancara awal yang dilakukan oleh peneliti (15/05/2016) dengan 3 orang remaja berjenis kelamin laki-laki dan perempuan berusia \pm 16 - 18 tahun yang berisiko penyalahgunaan NAPZA didapatkan informasi bahwa "pengguna NAPZA dapat berisiko penyalahgunaan 
NAPZA disebabkan karena faktor cobacoba pertama kali dari ajakan teman, remaja suka bersenang-senang dengan mengkonsumsi narkoba (pesta), dan terdapat juga konflik keluarga ayah dan ibu dengan kondisi keluarga yang bercerai. Partisipan yang merupakan pecandu NAPZA berawal dari berperilaku minum-minuman keras dan merokok yang dilakukan \pm 2 kali dalam satu minggu pesta minuman keras setiap pulang sekolah. Dapat disimpulkan bahwa faktor keluarga yang kurang harmonis disebabkan perceraian orang tua dan faktor teman sebaya yang memiliki kedekatan yang kuat, hal ini dapat menimbulkan remaja dapat terjerumus untuk melakukan perilaku penyalahgunaan NAPZA.

Kasus yang terjadi pada penyalahgunaan NAPZA di Indonesia khususnya di kota Solo mayoritas pada usia remaja. Hal ini dikarenakan remaja mudah dipengaruhi untuk mencoba menggunakan NAPZA dan sebagai salah satu cara untuk pencarian identitas yang masih labil.

Berdasarkan fenomena-fenomena di atas dapat disimpulkan bahwa di Kota Solo banyak terjadi kasus penyalahgunaan NAPZA yang terjadi dalam setiap tahunnya. Kasus pengguna penyalahgunaan NAPZA di Kota Solo mayoritas usia remaja. Remaja menjadi pengguna NAPZA di Kota Solo bersama temannya dan salah satu anggota keluarga ikut terlibat didalamnya. Penyebab dari remaja menjadi pengguna NAPZA dikarenakan faktor coba-coba, bujukan teman, dan senang-senang.

Penelitian Purwandari

memperoleh data yang mendukung bahwa remaja yang sedang menjalani rehabilitasi NAPZA yang memiliki pengaruh NAPZA dari teman sebesar $32 \%$. Selanjutnya Purwandari (2007) menemukan bahwa semua mantan penyalah- gunaan NAPZA menyatakan mengenal NAPZA dari teman sebaya. Pada kajian beberapa penelitian tersebut menunjukkan bahwa teman sebaya berpengaruh besar terhadap terbentuknya perilaku penyalahgunaan NAPZA.

Menurut Condry, Simon, dan Bronfenbrenner bahwa selama satu minggu, remaja laki-laki dan perempuan menghabiskan waktu 2 kali lebih banyak dengan teman sebaya daripada waktu dengan orang tuanya. Budaya dari teman sebaya remaja pun sebagai pengaruh negatif yang mengabaikan nilai-nilai kontrol dari orang tua. Teman sebaya juga dapat mengenalkan remaja dengan alkohol, obat-obatan, kenakalan, dan bentuk tingkah laku lain yang negatif (Santrock, 2003).

Dari beberapa fenomena dan penelitian yang telah dipaparkan, remaja yang berisiko penyalahgunaan NAPZA tidak hanya remaja laki-laki, tetapi ditemukan juga remaja perempuan berisiko penyalahgunaan NAPZA. Remaja yang berisiko penyalahgunaan NAPZA disebabkan oleh faktor eksternal, yaitu keluarga dan teman sebaya.

Fenomena perilaku penyalahgunaan NAPZA dalam penelitian ini dijelaskan dengan teori kontrol sosial. Teori kontrol sosial dipakai oleh Bahr, et al. (2005); Begue \& Roche (2008); Chriss (2007); Durkin, et al. (1999); Giordano (2012); Krohn \& Massey (1980); Lin \& Dembo (2008); Marcos, et al. (1986); Nakhaie, et al. (2000); Ozbay \& Ozcan (2006); Yu \& Gamble (2010); Wiatrowski, et al. (1981) untuk memahami perilaku penyalahgunaan NAPZA.

Teori kontrol sosial merupakan teori yang dikembangkan dengan konsep mengapa seseorang tidak melakukan perilaku penyimpangan (melakukan dan tidak melakukan merupakan sebuah pasangan). Jadi seseorang yang memiliki 
kontrol sosial kuat akan cenderung tidak terlibat pada perilaku antisosial. Faktor sosial mempunyai pengaruh dan sebagai kontrol munculnya perilaku yang menyimpang, termasuk risiko penyalahgunaan NAPZA.

Kontrol sosial menunjukkan bahwa pola perilaku prososial remaja berkembang karena mereka melekatkan diri pada lingkungan sosialnya, seperti: sekolah dan keluarga (Booth, et al., 2008). Pergaulan remaja kini diharapkan memiliki dampak positif yang mengarah pada prestasi. Pada kenyataannya sikap dan perilaku remaja memiliki akibat negatif yang memiliki risiko penyalahgunaan NAPZA. Risiko penyalahgunaan NAPZA dapat diartikan sebagai bentuk perilaku kenakalan yang dapat terjadi pada remaja untuk menjadi pengguna penyalahgunaan NAPZA.

Berdasarkan fenomena dan penelitian awal yang dilakukan oleh peneliti di Kota Solo dapat disimpulkan bahwa remaja Kota Solo memiliki potensi penyalahgunaan NAPZA tertinggi di Jawa Tengah. Remaja merupakan masa peralihan dari masa kanak-kanak menuju masa dewasa. Kenakalan yang ditimbulkan oleh remaja yang paling berat adalah melakukan penyalahgunaan NAPZA. Remaja yang berisiko penyalahgunaan NAPZA dapat dipengaruhi oleh faktor eksternal, diantaranya adalah faktor keluarga dan faktor teman sebaya. Kedua faktor tersebut sangat berkaitan erat dengan teori kontrol sosial yang memiliki empat aspek yang dapat mengontrol kenakalan pada anak, yaitu kelekatan, komitmen, keterlibatan, dan keyakinan. Keempat aspek tersebut peneliti dapat mengetahui dinamika kontrol sosial remaja yang berisiko penyalahgunaan NAPZA di dalam keluarga dan teman sebaya.

Menurut Hirschi (dalam Purwandari, 2011) Teori Kontrol Sosial me- nyebutkan adanya peran mikrosistem di dalam pembentukan kenakalan pada anak. Asumsi teori ini adalah koneksi sosial antara anak dengan keluarga, teman, sekolah dan lingkungan sosial lain. Pada lingkungan sosial yang mikro tersebut menurut Ngai \& Cheung (2005); Wester, et al. (2008) menyebutkan sebagai lingkungan eksternal dari anak dan diberlakukan aturan-aturan, nilai dan keyakinan yang bersifat konvensional. Menurut Hirschi (dalam Adilla, 2009) mengembangkan teori kontrol sosial untuk menjelaskan alasan seseorang dapat taat pada peraturan dan norma. Bentukbentuk kontrol sosial ini terdiri dari empat elemen, yaitu: attachment (kelekatan), commitment (komitmen), involvement (keterlibatan), dan beliefs (keyakinan).

Penyalahgunaanan narkoba yang dilakukan oleh seseorang dapat dipengaruhi oleh kurang kuatnya kontrol sosial lingkungan terhadap orang itu. Kontrol sosial berpotensi menentukan perilaku seseorang sesuai dengan norma sosial di lingkungan tersebut. Konteks ini juga menjelaskan bahwa seseorang yang mempunyai kontrol sosial yang kuat maka orang itu tidak akan melakukan penyimpangan yang menyalahi norma (Hirschi, 2001).

Menurut Kroener dan Fitzpartick (dalam Lestari, 2012) definisi keluarga berdasarkan tiga sudut pandang, yaitu definisi struktural, definisi fungsional, dan definisi intersaksional. Teman sebaya atau peers adalah anak-anak dengan tingkat kematangan atau usia yang kurang lebih sama. Salah satu fungsi terpenting dari kelompok teman sebaya adalah untuk memberikan sumber informasi dan komparasi di luar keluarga. Melalui kelompok teman sebaya remaja menerima umpan balik dari teman-teman mereka tentang kemampuan mereka. Remaja menilai apaapa yang mereka lakukan, apakah dia 
lebih baik daripada teman-temannya, sama, ataukah lebih buruk dari apa yang remaja-remaja lain kerjakan. Hal demikian akan sulit dilakukan dalam keluarga karena saudara-saudara kandung biasanya lebih tua atau lebih muda (bukan sebaya) (Santrock, 2003).

Perilaku penyalahgunaan NAPZA pada remaja dapat dipengaruhi dengan adanya kondisi remaja dengan teman sebayanya yang memiliki dinamika yang berbeda. Hal ini berkaitan dengan teori kontrol sosial yang dikemukakan oleh Hirschi (2001) bahwa teori kontrol sosial dapat mengontrol perilaku risiko penyalahgunaan NAPZA pada remaja yang faktor eksternal, yaitu keluarga dan teman sebaya.

Menurut Hirschi's social control/ bonding theory (Booth, et al., 2008; Wester et al., 2008; Ozbay \& Ozcan, 2006) kontrol sosial di dalam keluarga dan teman sebaya merupakan suatu kontrol perilaku dalam diri seseorang dari lingkungan internal maupun eksternal berdasarkan atas norma atau aturan yang ada dalam keluarga dan lingkungan teman sebaya.

Menurut Hirschi (2001) kelekatan merupakan faktor emosi dan menggunakan hati (perasaan). Hal ini mendeskripsikan bahwa anak memiliki kecenderungan untuk melekatkan diri pada orang lain. Kelekatan yaitu kemampuan individu untuk peka pada pikiran, perasaan, dan keinginannya. Jika individu mampu menilai dan mempertahankan hubungannya dengan orang lain maka akan sedikit kemungkinan mereka untuk berbuat jahat. Kelekatan menunjuk pada emosi atau keterlibatan afektif individu pada yang lain. Jika individu mampu menilai dan memperhatikan hubungannya dengan orang lain maka akan sedikit kemung-kinan mereka untuk berbuat jahat. Anak melakukan kelekatan ini dengan orang tua, sekolah, dan teman sebayanya yang di dalamnya termasuk supervisi orang tua, kualitas komunikasi, kebersamaan, pemahaman orang tua tentang pertemanan anaknya dan kepercayaan. Jika kelekatan anak kuat terhadap pihak tertentu, hal ini akan membentuk suatu komitmen antara anak dengan orang tua (Hirschi, 2001).

Menurut Nye (dalam Hirschi, 2001) terdapat penjelasan mengenai efek keterikatan kepada orang tua pada perilaku nakal dengan mengacu pada internalisasi norma (seperti yang terdapat di dalam teori kontrol sosial, dengan mengacu pada kontrol pribadi atau internal). Menurut Sutherland dan Cressey (dalam Hirschi, 2001) dalam teori penyimpangan budaya, kurangnya keterikatan dengan orang tua hanya meningkatkan anak akan terkena pengaruh kejahatan, bahwa anak akan mempelajari sikap, nilai, dan ketrampilan kondusif untuk melakukan kenakalan. Seorang anak yang bebas dari kontrol orang tua tidak cukup untuk menghasilkan hanya sebuah kenakalan.

Kelekatan teman sebaya bisa menjadi faktor risiko maupun faktor protektif. Kelekatan teman sebaya dengan jalinan komunikasi yang terbentuk, kepercayaan, dan seberapa besar keterlibatan teman terhadap remaja membawa pengaruh pada perilaku remaja, dalam hal ini perilaku risiko penyalahgunaan NAPZA.

Berdasarkan pemaparan di atas dapat disimpulkan bahwa kelekatan dalam keluarga dan teman sebaya dapat berhubungan pada perilaku risiko penyalahgunaan NAPZA. Hal ini dapat dijelaskan bahwa semakin kuatnya kelekatan keluarga pada remaja, maka akan menimbulkan lemahnya atau tidak adanya perilaku risiko penyalahgunaan NAPZA yang terjadi; dan semakin kuatnya kelekatan teman sebaya pada 
remaja, maka akan meningkatkan perilaku risiko penyalahgunaan NAPZA.

Komitmen merupakan komponen rasional dari suatu ikatan. Anak-anak memiliki suatu komitmen terhadap orang tuanya, yang berarti ketika anak mengalami suatu kelekatan terhadap orang tua, anak juga telah melakukan sebuah kesepakatan yang akan diungkapkan dalam perilaku. Hal ini mengacu pada sejauh mana anak-anak terlibat dalam kegiatan konvensional suatu kelompok. Sebelum seseorang melakukan tindakan kriminal mereka melewati proses rasional yang menimbang untung rugi tindakannya dibanding dengan investasi dalam konformitasnya. Contohnya seperti menghormati tradisi, dan percaya pada norma-norma dan nilai-nilai hidup yang berlaku di masyarakat (Hirschi, 2001).

Hal ini dapat disimpulkan bahwa semakin kuatnya komitmen yang terjadi antara remaja dengan orang tuanya, maka dapat dikatakan tidak adanya perilaku remaja yang berisiko penyalahgunaan NAPZA. Selanjutnya, pada komitmen teman sebaya dengan remaja yang erat setelah kelekatan sudah terjalin, maka dapat menimbulkan perilaku remaja untuk dapat melakukan kenakalan, yaitu penyalahgunaan NAPZA.

Menurut Hirschi (2001) keterlibatan anak berhubungan dengan seberapa banyak waktu yang dihabiskan seorang anak untuk berinteraksi dengan individu lain dalam suatu kegiatan. Jika interaksi yang tepat dengan kegiatan maupun seseorang dalam hal ini anak memiliki keterlibatan dengan orang tua, yang berarti keterlibatan yang ada diwujudkan ke dalam suatu tindakan (action).

Keterlibatan anak dengan orang tua, yaitu melakukan kegiatan secara bersamasama, misalnya: makan bersama-sama, olahraga bersama-sama, bertamasya, dan lain sebagainya. Namun sebaliknya jika interaksi dan kegiatan yang kurang tepat seperti bolos, tawuran, melawan orang tua, mencuri dan lainnya merupakan hal yang sering dilakukan anak maka kenakalan pun akan semakin mudah terbentuk dalam diri anak. Semakin individu terlibat dan asyik dalam konvensi sesuatu, semakin kecil kemungkinan untuk berbuat kriminal (Hirschi, 2001).

Hal ini dapat disimpulkan bahwa keterlibatan remaja dengan orang tua dengan melakukan kegiatan atau aktivitas bersama-sama secara positif akan dapat menurunkan perilaku remaja untuk berisiko penyalahgunaan NAPZA, dan sebaliknya yaitu keterlibatan yang terjadi antara remaja dengan teman sebayanya akan terjalin semakin kuat dengan adanya kegiatan atau aktivitas yang dilakukan bersama-sama dengan frekuensi yang sering dengan teman yang memiliki latar belakang pengguna NAPZA, hal ini akan memudahkan remaja dapat berisiko penyalahgunaan NAPZA.

Keyakinan yaitu kesediaan dengan penuh kesadaran untuk menerima segala aturan. Keyakinan dalam nilai moral dari norma konvensional merupakan komponen keempat dari ikatan sosial. Beberapa anak memiliki keyakinan yang lebih kuat dalam mengikatkan diri dalam aturan sosial, sehingga tidak cenderung berkomitmen terhadap kenakalan. Secara spesifik, teori kontrol sosial menekankan adanya supervisi dan perilaku moral dapat diberikan oleh orang tua sehingga dapat mengurangi angka kenakalan. Dalam hal ini keyakinan yang dibentuk anak dengan orang tua, yaitu anak dapat mentaati aturan-aturan atau norma yang telah diterapkan di dalam keluarga dengan baik (Hirschi, 2001).

Kenyamanan akan timbul ketika masing-masing keluarga memiliki kepercayaan satu sama lain. Beberapa anak 
memiliki belief atau keyakinan yang lebih kuat dalam mengikatkan diri dalam aturan sosial. Mereka akan lebih tidak cenderung berkomitmen terhadap kenakalan (Reggoli \& Hewitt, 2003).

Berdasarkan paparan yang telah dijelaskan di atas tentang kontrol sosial keluarga dan teman sebaya dapat disimpulkan bahwa dibutuhkan kontrol sosial yang mampu menjadi benteng dan mampu mengantisipasi perilaku risiko penyalahgunaan NAPZA pada remaja. Keterkaitan antar lembaga kontrol sosial akan mampu mengontrol terhadap perilaku risiko penyalahgunaan NAPZA. Keterkaitan antar lembaga kontrol sosial akan mampu mengontrol terhadap perilaku risiko penyalahgunaan NAPZA, yang terdiri dari keluarga, sekolah, dan pertemanan, baik langsung maupun tidak langsung.

Istilah Narkoba adalah kependekan dari narkotik dan obat-obatan berbahaya. Pihak pemerintah cenderung lebih senang dengan istilah NAPZA (Narkotika, Psikotropika, dan Zat Adiktif lainnya). Narkotika adalah zat yang bisa menimbulkan pengaruh tertentu bagi mereka yang mempergunakan dengan memasukannya ke dalam tubuh (Kaligis, 2002). Menurut Undang-Undang Republik Indonesia No. 35 Tahun 2009 yang dimaksud narkotika adalah zat atau obat yang berasal dari tanaman atau bukan tanaman, baik sintetis maupun semi sintetis, yang dapat menyebabkan penurunan atau perubahan kesadaran, hilangnya rasa, mengurangi sampai menghilangkan rasa nyeri, dan dapat menimbulkan ketergantungan, yang dibedakan ke dalam golongan-golongan sebagaimana terlampir dalam UndangUndang.

Menurut BNN (2009) menyatakan ciri-ciri remaja yang mempunyai risiko penyalahgunaanan NAPZA yaitu memi- liki sikap cenderung memberontak, perilaku menyimpang dari aturan atau norma yang ada, memiliki gangguan jiwa lain (depresi, cemas), kurang rasa percaya diri, mudah kecewa, agresif, destruktif, murung, pemalu, pendiam, memiliki keinginan untuk mencoba yang sedang mode/sesuatu yang baru, identitas diri kabur, kemampuan komunikasi rendah, baik komunikasi orang tua dan teman, kurang menghayati iman dan kepercayaan, merasa bosan/jenuh, putus sekolah, memiliki orang tua otoriter, hubungan dengan orang tua kurang harmonis, orang tua bercerai atau menikah lagi, orang tua terlalu sibuk/acuh, sekolah yang kurang disiplin, sekolah terletak dekat tempat hiburan, sekolah yang kurang memberi kesempatan pada siswa untuk mengembangkan diri secara kreatif dan positif, adanya murid yang menggunakan NAPZA.

Beberapa faktor risiko penyalahgunaanan NAPZA pada remaja menurut Papalia, Olds, dan Feldman (2009) antara lain: temperamen yang sulit, control impuls yang buruk dan kecenderungan untuk mencari sensasi (yang mungkin memiliki dasar biokimia), pengaruh keluarga (termasuk predisposisi genetik terhadap alkoholisme, penggunaan atau penerimaan NAPZA, praktik pengasuhan orang tua yang buruk atau tidak konsisten, konflik keluarga, dan hubungan keluarga yang terganggu atau jauh), masalah perilaku sejak dini dan menetap, terutama agresivitas, kegagalan di bidang akademis dan kurangnya komitmen terhadap pendidikan, penolakan teman sebaya, bergaul dengan pengguna NAPZA, keterasingan dan sifat memberontak, sikap positif terhadap penggunaan NAPZA, mencoba NAPZA sejak usia dini.

Menurut Steinberg (2014) masa remaja merupakan konstruksi teoritis yang dinamis dan berkembang melalui keadaan 
fisiologis, psikososial, temporal dan budaya. Masa perkembangan remaja dipahami secara konvensional seperti pada masa pubertas dan pembentukan kemandirian sosial. Masa remaja merupakan proses transisi yang terjadi secara kompleks melibatkan per-kembangan berawal dari ketidakdewasaan dan ketergantungan sosial pada masa kanakkanak menuju ke masa dewasa dengan tujuan dan harapan dari potensi perkembangan yang telah terpenuhi, keadaan pribadi, dan akuntabilitas sosial (Greenfield, Keller, Fuligni, \& Maynard 2003; Graber \& Brookes-Gunn, 1996; Modell \& Goodman, 1990, Steinberg, 2002). Transisi perkembangan yang terjadi selama masa remaja membutuhkan reorganisasi timbal balik individu dan konteks yang dapat memengaruhi kognisi, emosi, perilaku, dan hubungan (Graber \& Brooks-Gunn, 1996; Lerner \& Castellino, 2002).

Batasan usia remaja menurut Monks, et al. (2002) sebagai berikut: a) 10-12 tahun termasuk dalam masa pra-remaja, b) 12-15 tahun termasuk dalam masa remaja awal, c) 15-18 tahun termasuk dalam masa remaja pertengahan, dan d) 18-21 tahun termasuk dalam masa remaja akhir.

Menurut Lustin (1976) tugas perkembangan remaja tengah dan akhir adalah menerima keadaan fisik sebagai suatu perubahan, mencapai kebebasan emosional dari orang tua dan figur otoritas lainnya, mengembangkan keterampilan dalam komunikasi interpersonal dan belajar untuk berteman baik dalam teman sebaya maupun kelompok lain, menemukan figur yang tepat untuk dijadikan sebagai model dalam mencapai identitas ego, menyadari dan menggunakan potensi yang dimiliki sebagai kemampuan, menguatkan kontrol diri, menjadi lebih dewasa dalam berperilaku dan penyesuaian yang lebih baik dibanding masa sebelumnya.

Teori kontrol sosial juga menyatakan bahwa perilaku risiko penyalahgunaan NAPZA muncul karena lemahnya atau tidak ada kontrol dari orang dalam lembaga dan atau lembaga di mana seseorang berada, yang terdiri dari kelekatan, komitmen, keterlibatan, dan keyakinan (Hirschi, 1969, 2002).

Berdasarkan uraian di atas tentang dinamika kontrol sosial keluarga dan teman sebaya pada remaja dengan empat aspek kontrol sosial dapat disimpulkan bahwa keempat pola tersebut sangat berhubungan satu sama lain dan berkaitan erat dengan remaja, keluarga, dan teman sebaya. Kontrol sosial dibutuhkan untuk mampu menjadi benteng dan mampu mengantisipasi perilaku risiko penyalahgunaan NAPZA pada remaja. Keterkaitan antar lembaga kontrol sosial akan mampu mengontrol terhadap perilaku risiko penyalahgunaan NAPZA akan mampu mengontrol terhadap perilaku risiko penyalahgunaan NAPZA, yang terdiri dari keluarga, sekolah, dan pertemanan, baik langsung maupun tidak langsung.

\section{Metode}

Peneliti menggunakan perspektif IPA (Interpretative Phenomenological Analysis). IPA berfokus pada pengujian mendetail tentang pengalaman yang dialami individu. IPA merupakan pendekatan kualitatif, eksperensial, dan psikologis yang terbentuk oleh konsep-konsep dari area filsafat pengetahuan yaitu fenomenologi, hermeneutika, dan idiografi. IPA menghubungkan ketiga hal tersebut dengan intelektualitas fenomenologi, hermeneutika, dan psikologi tentang pengalaman subjektif dan personal /ideografik (Smith, Flowers \& Larkin, 2009). 
Kontrol sosial yang menjadi variabel dalam penelitian ini merupakan istilah untuk memahami makna pada remaja berisiko penyalahgunaan NAPZA. Bagaimana remaja yang berisiko penyalahgunaan NAPZA dapat dipengaruhi oleh kontrol sosial (keluarga dan teman sebaya) yang dialaminya. Remaja berisiko penyalahgunaan NAPZA tersebut akan dimaknai secara berbeda dikarenakan peneliti untuk mengetahui dinamika kontrol sosial keluarga dan teman sebaya.

\section{Partisipan Penelitian}

Penelitian ini dilakukan di Sekolah Menengah Atas (SMA) yang berisiko penyalahgunaan NAPZA Kota Solo. Prosedur penentuan partisipan pada penelitian ini menggunakan teknik non probability sampling yaitu pendekatan purposive sampling, untuk memilih partisipan diantara populasi yang sesuai dengan tujuan penelitian dan dipilih mengikuti kriteria tertentu berdasarkan teori atau konstruk operasional agar mewakili (bersifat representatif) terhadap fenomena yang diteliti (Poerwandari, 1998). Penelitian ini berfokus pada partisipan yang berisiko penyalahgunaan NAPZA dengan kriteria sebagai berikut: (a) bersedia menjadi partisipan, (b) berjenis kelamin laki-laki atau perempuan, (c) remaja yang berusia \pm 15 - 18 tahun, (d) remaja yang diindikasikan berisiko penyalahgunaan NAPZA.

Informan utama dalam penelitian ini yang digunakan dengan metode wawancara mendalam yaitu terdiri dari remaja laki-laki atau perempuan yang berusia $\pm 15-18$ tahun, yang diindikasikan berisiko penyalahgunaan NAPZA. Informan pendukung pada penelitian ini yaitu extended family dari remaja laki-laki atau remaja perempuan yang terdiri orang tua informan; dan teman sebaya dari informan. Penelitian pada metode pe- ngumpulan data berdasarkan wawancara mendalam dipilih berdasarkan atas kesediaan masing-masing informan untuk pengambilan data.

Pengumpulan data menggunakan kuesioner tertutup untuk melakukan screening, wawancara, dan observasi. Analisis data mengacu pada Smith, Flowers, dan Larkin (2010) yaitu membaca berulang-ulang data orisinil dalam transkrip wawancara, pencatatan awal dengan komentar-komentar eksploratoris, mengembangkan tema-tema yang muncul, mencari hubungan-hubungan di antara tema-tema yang muncul, beralih pada kasus berikutnya, dan mencari pola-pola diantara kasus-kasus. Verifikasi dilakukan dengan triangulasi, deskripsi secara kaya dan padat, dan serta pengecekan konsistensi.

\section{Hasil}

\section{Informan U}

Keluarga U merupakan figur keluarga yang bahagia lengkap dengan ayah dan ibu masih tinggal satu rumah, hal ini dapat terlihat dari kontrol keluarga yaitu kelekatan, komitmen, keterlibatan, dan keyakinan yang kuat untuk mengontrol perilaku anak tidak berperilaku yang negatif. Selanjutnya pada informan U kontrol teman sebaya yang ada dalam lingkungan keluarga $U$ yang terlihat juga pada aspek kelekatan, komitmen, keterlibatan, dan keyakinan yang sangat kuat membuat informan $U$ melakukan minum-minuman keras dan merokok bersama teman-temannya. Dalam hal ini keadaan keluarga $U$ yang bahagia dengan didukung aspek-aspek kontrol keluarga yang ada, tidak selaras dengan perilaku yang ditunjukkan oleh orang tua $U$, khususnya ayah U. Ayah U menunjukkan perilaku di lingkungan keluarga dengan minum-minuman keras bersama dengan 
teman ayah $U$ tersebut. Hal ini membuat remaja berisiko penyalahgunaan NAPZA.

\section{Informan B}

Keluarga B merupakan figur keluarga yang tidak bahagia, yang disebabkan karena kondisi orang tua informan B mengalami perceraian dan sudah tidak tinggal satu rumah. Kondisi ayah yang sudah menikah dan tinggal di Malaysia dan ibu yang menikah dan tinggal di Jakarta. Kedekatan yang kurang dengan intensitas komunikasi jarang membuat kontrol keluarga yang ada misalnya kelekatan, komitmen, keterlibatan, dan keyakinan semakin lemah. Informan B memiliki kedekatan dengan teman sebaya lebih kuat daripada bersama dengan keluarga. Kedekatan dengan teman sebaya membuat terjadinya konformitas antar teman sebaya yang berakibat tidak dapat menolak ajakan teman, khususnya perilaku negatif. Hal ini membuat remaja berisiko penyalahgunaan NAPZA.

\section{Informan E}

Keluarga E memiliki figur yang sama seperti keluarga B yaitu keluarga yang tidak bahagia, yang disebabkan karena kondisi orang tua informan $\mathrm{E}$ mengalami perceraian dan tidak tinggal satu rumah. Kondisi ayah informan $\mathrm{E}$ yang menikah lagi dan tinggal di desa, kemudian ibu informan $\mathrm{E}$ yang pindah dari desa ke kota dan tinggal bersama informan E. Keluarga informan E kurang memiliki kelekatan, komitmen, keterlibatan, dan keyakinan dengan ibu, walaupun informan $\mathrm{E}$ hanya tinggal bersama ibu. Hal ini disebabkan karena faktor lingkungan teman sebaya yang sangat memengaruhi informan E untuk lebih secara intens berkomunikasi dan melakukan kegiatan bersama-sama dengan teman sebaya. Perpindahan tempat tinggal informan $\mathrm{E}$ dari desa ke kota membuat informan $\mathrm{E}$ mengalami kurang bisa menyesuaikan dengan lingkungan, dan terpengaruh dengan lingkungan, misalnya: merokok dan minum-minuman keras. Hal ini membuat informan $\mathrm{E}$ berisiko penyalahgunaan NAPZA.

\section{Informan L}

Keluarga L memiliki figur keluarga yang sama dengan keluarga E dan B yaitu keluarga yang tidak bahagia yang disebabkan karena kondisi orang tua informan L mengalami perceraian dan tidak tinggal satu rumah. Kondisi ayah yang telah menghamili adik dari ibu informan $\mathrm{L}$ dan kondisi ibu yang menikah dengan musuh dari informan $\mathrm{L}$, hal ini membuat informan L merasa perasaannya hancur dan sudah tidak ada kedekatan dengan keluarga. Informan L lebih dekat dengan teman sebayanya dengan melakukan kegiatan bersama dan intensitas komunikasi lebih sering daripada dengan orang tuanya. Hal ini menyebabkan informan $\mathrm{L}$ berisiko penyalahgunaan NAPZA.

\section{Diskusi}

Penelitian ini mempertegas bahwa remaja memiliki pengaruh genetik yang lebih besar untuk melakukan perilaku anti sosial. Model ayah yang negatif membentuk remaja melakukan konformitas perilaku yang ada. Hal ini sesuai temuan dari Beaver, et al. (2009) (dalam Steinberg, 2011) bahwa pengaruh genetik (keluarga) terhadap perilaku anti sosial lebih kuat pengaruhnya daripada remaja yang memiliki teman sebaya. Selain itu sesuai dengan penelitian Dick, et al. (2007) (dalam Steinberg, 2011) yang menyatakan bahwa pengaruh genetik pada remaja yang merokok lebih kuat di kalangan remaja yang orang tuanya tidak memantau secara ketat. 
Penelitian menemukan kelekatan dengan orang tua dan tuntutan peran antara ayah dan ibu, dimana ibu lebih pada pemenuhan afeksi karena terdapat ikatan biologis antara ibu-anak, sedangkan ayah lebih pada kebutuhan sosial (Olson, DeFrain, \& Skogrand, 2011). Ibu yang mempunyai kemampuan menganalisa akan mampu mengelola dan mencari solusi ketika anak remaja membutuhkan bantuan secara afeksi, khususnya yang berkaitan dengan perilaku risiko penyalahgunaan NAPZA. Adanya pengaruh kedekatan dengan teman sebaya juga terdapat pada beberapa penelitian terdahulu (Curran, et al., 1997; Dolcini \& Adler., 1994; Wills \& Cleary, 1999) yang menyatakan bahwa teman sebaya merupakan faktor risiko utama penyalahgunaan NAPZA. Pada hasil wawancara dalam penelitian ini teman yang dianggap dekat oleh remaja yang berisiko penyalahgunaan NAPZA adalah mayoritas keempat informan utama memiliki teman dekat yang berpengaruh pada perilaku risiko penyalahgunaan NAPZA, sehingga kelekatan teman sebaya berpengaruh kuat terhadap perilaku risiko penyalahgunaan NAPZA.

Selanjutnya, komitmen dalam keluarga sesuai dengan teori yang dikemukakan oleh Hirschi (2001) menyatakan bahwa anak-anak memiliki suatu komitmen terhadap orang tuanya, yang berarti ketika anak mengalami suatu kelekatan terhadap orang tua, anak juga telah melakukan sebuah kesepakatan yang akan diungkapkan dalam perilaku. Hal ini berlaku pada komitmen remaja dengan teman sebaya pada perilaku berisiko penyalahgunaan NAPZA. Akan tetapi hal ini tidak sesuai dengan hasil penelitian Caprara, et al. (Carlk \& Shields, dalam Brank et al., 2008) menunjukan bahwa keluarga yang mudah berkomunikasi satu sama lain dapat mengurangi perilaku kenakalan anak. Hal ini disebabkan karena komunikasi yang dilakukan informan hanya sebatas komunikasi lewat media internet dan telepon, bukan lewat pertemuan fisik.

Penelitian juga menemukan bahwa remaja yang memiliki kedekatan dengan keluarga melakukan perilaku minumminuman keras dan merokok. Hal ini tidak sesuai dengan Hirschi (2001), keterlibatan anak dengan orang tua, yaitu melakukan kegiatan secara bersama-sama, misalnya: makan bersama-sama, olahraga bersama-sama, bertamasya, dan sebagainya. Semakin individu terlibat dan asyik dalam konvensi sesuatu, semakin kecil kemungkinan untuk berbuat kriminal. Penelitian Igra \& Moos (1979, dikutip dari Durkin, et al., 1999); Durkin, et al. (1999) menemukan bahwa keterlibatan kegiatan mengisi waktu luang berpengaruh terhadap perilaku minumminuman keras.

Aturan dalam keluarga tentang penanaman prinsip dan budi pekerti yang tidak konsisten diajarkan dalam keluarga remaja yang bercerai membuat remaja tidak mematuhi peraturan yang ada dalam keluarga. Ketidakjelasan penegakan aturan yang berlaku sesuai dengan temuan Way, et al. (2007) yang menyatakan bahwa jika aturan tidak ditegakkan dan pemberlakuan aturan secara konsistensi tidak ada, maka untuk antisipasi bentuk penyimpangan perilaku kurang kuat.

Dinamika kontrol sosial keluarga dan teman sebaya pada remaja berisiko penyalahgunaan NAPZA memilki empat aspek yang berperan di dalamnya, antara lain: kelekatan, komitmen, keterlibatan dan keyakinan yang masing-masing berhubungan satu sama lain. Pada kontrol keluarga keempat aspek dari kontrol sosial tersebut lemah yang didukung adanya permasalahan dalam keluarga dan kontrol keluarga kurang berperan dalam 
membentuk ikatan yang kuat antara keluarga dan remaja. Hal ini disebabkan oleh lemahnya faktor proteksi dalam keluarga. Selanjutnya, pada kontrol teman sebaya dengan remaja berisiko penyalahgunaan NAPZA memiliki ikatan yang kuat terhadap empat aspek tersebut. Hal ini disebabkan oleh kuatnya faktor risiko yaitu adanya konformitas antar teman sebaya untuk melakukan kegiatan yang kurang bermanfaat dan konflik yang terjadi dalam keluarga yang mengakibatkan remaja berperilaku penyalahgunaan NAPZA. Hal ini menyebabkan remaja berisiko penyalahgunaan NAPZA. Hal ini selaras dengan tugas perkembangan remaja yang kurang mencapai fungsi yang maksimal dalam perkembangannya, remaja lebih memiliki ikatan yang kuat dengan teman dan menimbulkan konformitas antar teman sebaya. Konformitas antar teman sebaya dengan melakukan perilaku kurang bermanfaat yaitu minum-minuman keras, merokok, dan sampai menggunakan pil ekstasi, hal ini berperan besar dalam membentuk perilaku remaja berisiko penyalahgunaan NAPZA.

\section{Kesimpulan}

Berdasarkan hasil analisis pada kuesioner tertutup dan wawancara mendalam, sekaligus dengan pembahasan penelitian maka dapat disimpulkan pada penelitian bahwa Dinamika Kontrol Sosial Keluarga dan Teman Sebaya Pada Remaja Berisiko Penyalahgunaan NAPZA dapat dideskripsikan sebagai berikut: Kontrol sosial dalam keluarga yang tidak harmonis (broken) dapat membuat remaja berisiko penyalahgunaan NAPZA melakukan pelanggaran atau perilaku yang dapat berlanjut terutama ketika kelekatan antara anak dengan anggota keluarga merenggang; kelekatan dalam keluarga dengan remaja yang ditunjukkan dengan intensitas orang tua berkomunikasi lewat saluran telepon atau dunia internet membuat kelekatan antara orang tua dengan remaja lebih rendah daripada berkomunikasi pertemuan secara fisik; kontrol sosial pada remaja berisiko penyalahgunaan NAPZA pada keluarga yang tidak harmonis (broken) sudah tidak memiliki peran di dalamnya; pengaruh konformitas teman sebaya yang begitu kuat dengan adanya keterlibatan kegiatan yang kurang bermanfaat sehingga membuat remaja berisiko penyalahgunaan NAPZA; remaja yang diawali dengan berperilaku merokok, mengonsumsi minum-minuman keras dan lingkungan keluarga maupun teman sebaya sangatlah berpengaruh terjadinya perilaku penyalahgunaan NAPZA.

Dinamika kontrol sosial keluarga dan teman sebaya pada remaja berisiko penyalahgunaan NAPZA memilki empat aspek yang berperan di dalamnya, antara lain: kelekatan, komitmen, keterlibatan dan keyakinan yang masing-masing berhubungan satu sama lain. Pada kontrol keluarga keempat aspek dari kontrol sosial tersebut lemah yang didukung adanya permasalahan dalam keluarga dan kontrol keluarga kurang berperan dalam membentuk ikatan yang kuat antara keluarga dan remaja. Hal ini disebabkan oleh lemahnya faktor proteksi dalam keluarga. Selanjutnya, pada kontrol teman sebaya dengan remaja berisiko penyalahgunaan NAPZA memiliki ikatan yang kuat terhadap empat aspek tersebut. Hal ini disebabkan oleh kuatnya faktor risiko yaitu adanya konformitas antar teman sebaya untuk melakukan kegiatan yang kurang bermanfaat dan konflik yang terjadi dalam keluarga mengakibatkan remaja berperilaku penyalahgunaan NAPZA. Hal ini menyebabkan remaja berisiko penyalahgunaan NAPZA. 


\section{Saran}

Pada penelitian remaja berisiko penyalahgunaan NAPZA yang sebelumnya sudah ada kontrol keluarga dan teman sebaya, sebaiknya ditambahkan dengan adanya kontrol sekolah dan kontrol komunitas. Mengingat bahwa lingkungan sekolah dan komunitas berpengaruh secara langsung terhadap masalah perilaku pada remaja.

Secara konseptual pada penelitian lanjutan, sebaiknya menambahkan faktorfaktor lain perlu dikaji, seperti faktorfaktor internal yang belum dilibatkan di dalam penelitian ini seperti: konsep diri, kontrol diri, harga diri, kecemasan, keterampilan pengambilan keputusan, percaya pada kemampuan, kemampuan memecahkan masalah. Kemudian sebaiknya dilakukan kajian mendalam terkait aspek kontrol sosial yang belum diteliti pada penelitian ini dan melakukan tindakan prevensi sedini mungkin untuk remaja di sekolah atau lingkungan yang berpotensi membentuk remaja berisiko penyalahgunaan NAPZA.

\section{Kepustakaan}

Adilla, N. (2009). Pengaruh kontrol sosial terhadap perilaku bullying pelajar di Sekolah Menengah Pertama. Jurnal Kriminologi Indonesia, 5(1), 56-66

Afiatin, T. (2008). Pencegahan penyalahgunaaan narkoba dengan program AJI. Yogyakarta: Gadjah Mada University Press.

Akers, R. L., \& Jensen, G. F. (2006). The empirical status of social learning theory of crime and deviance: The past, present, and future. In F. T. Cullen, J. P. Wright, \& K. R. Blevins (Eds.), Taking stock: The status of criminological theory, 37-76. New Brunswick: Transaction Publishers.
Akers, R. L., Krohn, M. D., Lanza-Kaduce, L, Radosevich, M. (1979). Social learning and deviants behavior: A specific test of a general theory. American Sociological Review, 44(4), 636-655. doi: 10.2307/2094592

Bahr, S. J., Hoffmann, J. P., \& Yang, X. (2005). Parental and peer influences on the risk of adolescent drug use. The Journal of Primary Prevention, 26(6), $529-551$.

Barnes, G. M., Hoffman, J. H., Weltw, J. W., Farrel, M. P., \& Dintcheff, B.A. (2006). Effects of parental monitoring and peer deviance on substance use and delinquency. Journal of Marriage and Family, 68(4), 1084-1105

Begue, L., \& Roche, S. (2008). Multidimensional social control variables as predictors of drunkeness among French Adolescents. Journal of Adolescence, 1-21. doi: 10.1016/ j.adolescence.2008.04.001

Booth, J. A., Farrell, A \& Varano, S. P (2008). Social control, serious delinquency, and risky behavior : A tendered analysis. Crime $\mathcal{E}$ Delinquency.

http://cad.sagepub.com/content/54/3/ 423. Diakses Tanggal 27 September 2015

Brank, Carl, Shield (2008). Communication in Family. http://cad.sagepub.com/ content/53/3/423. Diakses Tanggal 27 Januari 2015

Budiyanto, R. (2012). Waspada sepuluh kabupaten kota di jateng rawan narkoba.

http://tvOneNewsWaspada, Sepuluh.Kabupaten.Kota.di.Jateng.R awan.Narkoba-Nusantara.htm.

Diakses Tanggal 24 September 2013.

Calafat, A., Fernandez, C., Juan, M., \& Becon, E. (2008). Recreational nightlife: Risk and protective factors for drug misuse among young 
europeans in recreational environments. Drugs: Education, Prevention and Policy, 15(2), 189-200. doi: $10.1080 / 09687630701267366$

Chris, J. J. (2007). The function of the social bond. Sociological Quarterly. 48(4), 687-712. doi: 10.1111/j.1533-8525. 2007.00097.x

Connell, C. M., Gilreath, T. D., Aklin, W. M., \& Brex, R. A. (2010). Socialecological influences on patterns of substance use among nonmetropoloitan high school students. American Journal Community Psychology, 45(1-2), 36-48. doi: 10. 1007/s10464-009-9289-x

Curran, P. J., Stice, E., \& Chassin, L. (1997). The relation between adolescent alcohol use and peer alcohol use : A longitudinal random coefficient model. Health Psychology, 65(1), 130140. doi: 10.1037/0022-006X.65.1.130

Data Kasus Tindak Pidana Kasus Narkoba di Indonesia Tahun 1997-2008. Reporter. Dit IV/TP Narkoba \& KT Bareskrim Polri 130 Januari 2009. http://www.bnn.qo.id/portalbaru/po rtal/konten.php?narna=DataKasus\& or

Davis, C., Tang, C, \& Ko, J. (2004). The impact of peer, family and school on delinquency: A study of at risk chinese adolescents in Hongkong. International Social Work, 47, 489-502

Dishion, T. J., Capaldi, D. M., \& Yoerger, K. (1999). Middle chidhood antecendents to progressions in male adolescent substance use: An ecological analysis of risk and protection. Journal of Adolescent Research, 14(2), 175-205. doi: 10.1177/ 0743558499142003

Dolcini, M. M \& Adler, N. E. (1994). Perceived competencys, peer group affiliation, and risk behavior among early adolescents. Health Psychology,
13(6), 496-506. doi: 10.1037/02786133.13.6.496

Drapela, L. A. (2006). Investigating the effects of family, peer, and school domains on postdroupout drug use. Youth \& Society. 37(3), 316-347. doi: 10.1081/JA-100102631

Durkin, K., Wolfe, S. E., \& Clark, G. (1999). Social bond theory and binge drinking among college students: A multivariate analysis. College Student Journal, 33, 450-462.

Fleming, C. B., Catalano, R. F., Haggerty, K. P., \& Abbott, R. D. (2010). Relationships between level and change in family, school, and peer factors during two periods of adolescence and problem behavior at age 19. Journal Youth Adolescence, 39(6), 670-682. doi: 10.1007/s10964010-9525-5

Gatins, D. E. \& White, R. M. (2006). School based substance abuse programs: Can they influence students' knowledge, attitudes, and behaviors related to substance abuse?. North American Journal of Psychology, 8(3), 517-532.

Gerra, G., Angioni, L., Zaimovic, A., Moi, G., Bussandri, M., Bertacca, S., Santoro, G., Gardini, S., Caccavari, R., Nicoli, M. A. (2004). Substance use among high-school students: Relationships with temperament, personality traits, and parental care perception. Substance Use \& Misuse, $39(2)$, 345-367. doi: 10.1081/JA120028493

Girodano, A. L. (2012). Social interest and social bonding: Understanding colligiate hazardous drinking and marijuana use. Dissertation. University of North Carolina.

Haddad, L., Shotar, A., Umlauf, F., \& Alzyoud, S. (2010). Knowledge of substance abuse among high school 
students in Jordan. Journal of Transcultural Nursing, 21(2), 143-150. doi: $10.1177 / 1043659609357632$

Herman, R. M. J. (2005). Faktor-faktor yang berhubungan dengan penyalahgunaan NAPZA (Narkotika, Psikotropika, \& Zat Adiktif) kalangan siswa SMU. Pusat Penelitian dan Pengembangan Farmasi. Badan Penelitian dan Pengembangan Kesehatan Departemen Kesehatan RI. Jakarta .- www.kalbe.co.id/

Hirschi, T (1969). Causes of delinquency. Berkeley : University of California

Hirschi, T (2001). Causes of delinquency. New Brunswick, N.J. : Transaction

Hirschi, T. (2002). Cause of delinquency. New Jersey: New Brunswick.

Kaligis, O. C; \& Dirdiosisworo, S. (2002). Narkoba dan peradilannya di Indonesia: Reformasi hukum pidana melalui perundangan dan peradilan. Ed.1. Bandung: Alumni.

Kaplow, J. B., Curran, P. J., Dodge, K. A., \& The conduct problems prevention research group. (2002). Child, parent, and peer predictors of early-onset substance use: A multisite longitudinal study. Journal Abnormal Child Psychology, 30(3), 199-216.

Krohn, M. B. \& Massey, J. L. (1980). Social control and delinquent behavior. An Examination of the elements of the social bond. The Sociological Quarterly, 21(4), 529-543. doi: 10. 1111/j.1533-8525.1980.tb00634.x

Lestari, S. (2012). Psikologi keluarga penanaman nilai dan penanaman konflik dalam keluarga. Jakarta: Kencana Prenada Media Group

Lin, W. H. \& Dembo, R. (2008). An integrated model of juvenile drug use: A cross-demographic groups study. Western Criminology Review, 9(2), 33-51.
Lustin, P. (1976). Human development. Tokyo: McGraw-Hill

Marcos, A. C., Bahr, S. J., \& Johnson. R. E. (1986). Test of a bonding/association theory of adolescent drug use. Social Force, 68(1), $135-160$.

Maslim, R. (2001). Diagnosis gangguan jiwa, Rujukan ringkas PPDGJ-III. Jakarta: Unika Atma Jaya.

Monks, F. J., Knoers, A. M. P., \& Haditono, S. R. (2002). Psikologi perkembangan: Pengantar dalam berbagai bagaiannya. Yogyakarta: Gadjah Mada University Press

Nakhaie, R. M., Silverman, R. A., \& LaGrange, T. C. (2000). Self -control and social control : An Examination of gender, ethnicity, class and delinquency. Canadian Journal of Sociology, 25(1), 35 - 59.

Ngai, N. P \& Cheung, C. K. (2005). Predictors of the likehood of delinquency: A study of marginal youth in Hong Kong China. Youth $\mathcal{E}$ Society, 36(4), 445-470

Olson, D. H., DeFrain, J., \& Skogrand, L. (2011). Marriages families: Intimacy, diversity, and strengths. Seventh Edition. New York: The McGrawHill Companies, Inc.

Ozbay, O \& Ozcan, Y. Z. (2006). A test of Hirschi's social bonding theory: Juvenile delinquency in the high school of Ankara, Turkey. International Journal of Offender Therapy and Comparative Criminology, 50(6), 711-726. doi: 10.1177/03066 24X05283525

Puente, C. N., Gutierrez, J. L. G., Abella'n, 1. C. \& Lopez, A. P. (2008). Sensation seeking, attitudes toward drug use, and actual use among adolescents: Testing a model for alcohol and ecstasy use. Substance Use E Misuse, 43(11), 1618-1630. doi: 10.1080/ 10826080802241151 
Purwandari, E \& Lestari, R. (2012). Model lklim sekolah pada remaja berisiko tinggi penyalahgunaan NAPZA. Laporan Penelitian.

Purwandari, E (2011). Keluarga, kontrol sosial dan "strain": Model kontinuitas delinquency remaja. Humanitas: Jurnal Psikologi Indonesia, 8(1), 28-44

Purwandari, E. (2005). Orientasi nilai-nilai hidup remaja menuju kebermaknaan hidup. Proceedings. Temu Ilmiah Nasional ke-4 Ikatan Psikologi Perkembangan Indonesia (IPPI), Semarang, 8-10 September 2005. Hal. 82-91.

Purwandari, E. (2007). Orientasi nilai-nilai hidup: Proses pengambilan keputusan berhenti mengkonsumsi NAPZA. Jurnal Penelitian Humaniora, 8(2), 148-165

Regoli, R. M \& Hewitt, J. D (2003). Delinquency in society: Fifth edition, New York: McGraw Hill Companies, Inc.

Santrock, J. W. (2003). Adolescence (Perkembangan remaja). Terjemahan. Jakarta: Penerbit Erlangga.

Smith, J. A., Flowers, P., \& Larkin, M. (2010). Interpretative phenomenological analysis-theory, method, and research. London: Sage Publications.

Steinberg, L. (2011). Adolescence (Ninth edition). New York: McGraw-Hill International Edition.

Sugiyono. (2010). Metode penelitian kuantitatif kualitatif dan RED. Bandung: CV. Alfabeta I

Way, N., Reddy, R., \& Rhodes, J. (2007). Students' perceptions of school climate during the middle school years: Associations with trajectories of psychological and behavioral adjustment. American Journal Community Psychology, 40(3-4), 194213. doi: $10.1007 / \mathrm{s} 10464-007-9143 y$

Wester, S. R. (2008). Male gender role conflict and multiculturalism: Implications for counseling psychology. The Counseling Psychologist, 36, 294-324. doi: 10. 1177/0011000006286341.

Wiatrowski, M. D., Griswold, D. B., \& Roberts, M. K. (1981). Social control. Theory and delinquency. American Sociological Review, 46, 525 - 541.

Wills, T. A. \& Clearly, S. D. (1999). Peer and adolescent substance use among 6th-9th graders: Latent growth analysis of influence versus selection mechanism. Health Psychology, 18(5), 453-463. doi: 10.1037/0278-6133. 18.5.453

Yanny, L. D. (2001). Narkoba pencegahan dan penanganannya. Jakarta: Elex Media Komputindo.

Yu, J. J., \& Gamble, W. C. (2010). Direct and moderating effects of social affordances on school involvement and delinquency among young adolescents. Journal of Research on Adolescent. 20(4), 811 - 824. 